\title{
Coronary heart disease among workers exposed to carbon disulphide
}

\author{
S. HERNBERG, T. PARTANEN, C-H. NORDMAN, and P. SUMAR, \\ Institute of Occupational Health, Helsinki, Finland
}

Hernberg, S., Partanen, T., Nordman, C-H., and Sumari, P. (1970). Brit. J. indust. Med., 27, 313-325. Coronary heart disease among workers exposed to carbon disulphide. Coronary morbidity and some coronary risk factors were studied among workers in a viscose rayon plant. All men with at least five years' exposure to carbon disulphide during any period between 1942 and 1967 were included. In all, 410 men complied with these criteria. Of them, 45 had died and no information was obtained for nine. Three hundred and forty three men attended the examination which included, among other things, electrocardiography after a standardized exercise test, measurement of blood pressure, and a chest radiograph.

The concentration of $\mathrm{CS}_{2}$ and $\mathrm{H}_{2} \mathrm{~S}$ had been regularly measured by the plant laboratory from 10 to 40 different sites since 1950. In all, some 3000 measurements were available. The concentrations have probably been very high in the $1940 \mathrm{~s}$, about 20 to $40 \mathrm{ppm}$ in the $1950 \mathrm{~s}$, and about 10 to $30 \mathrm{ppm}$ in the $1960 \mathrm{~s}$.

The exposed men were individually matched with controls from a paper mill, situated in the same city. Age, birth district, and similarity of work were taken into account in the matching. Smoking habits, leisure time physical activity, physical fitness, obesity, and drug therapy were checked at the examination; no practically important differences were found.

Comparisons were made for the whole group, for spinners, for those exposed for 15 years or more, and for those with an exposure index (sum of products of duration and intensity of exposure) of more than the mean value of the whole group.

The exposed subjects had higher mean systolic and diastolic blood pressures in all comparisons. The differences were statistically significant. The frequency of a history of angina was slightly higher among the exposed subjects; this difference also was statistically significant. A history of infarction was slightly more frequent in the control group, but the difference was not statistically significant. Although the commonly used limits for statistical significance were not achieved for any isolated electrocardiographic finding, classified according to the Minnesota code, there was a slightly higher prevalence of several pathological findings ascribable to coronary heart disease in the exposed group.

An excess of coronary deaths was observed for 48 men who had been exposed for at least five years and who had died under 65 years of age. The expected number was $15 \cdot 2$, while the observed number was 25 : the difference was statistically significant $(P<0.002)$.

Although no definite evidence was found, the excess of coronary deaths in combination with the small hint of a higher prevalence of pathological electrocardiograms among the exposed subjects suggest that $\mathrm{CS}_{2}$ may be an aetiological factor in the pathogenesis of coronary heart disease.

It has long been known that overexposure to carbon disulphide $\left(\mathrm{CS}_{2}\right)$ may cause central and peripheral neurological disturbances in human beings (Vigliani,
1954; Vigliani and Pernis, 1955; Vigliani, 1961; Brieger, 1961; Minden, 1967). CS $_{2}$ also seems to promote atherosclerosis. Indirect evidence for this 
hypothesis has accumulated from a number of studies showing disturbances, provoked by $\mathrm{CS}_{2}$, in the lipid metabolism of experimental animals and of man. Such disturbances are known to be of significance in the development of atherosclerosis (Ruikka, 1959; Harashima, Toyama, and Sakurai, 1960; Vigliani, 1961; Přerovská and Srbová, 1963; Martino, Perrelli, and Coscia, 1964; Toyama and Sakurai, 1967; Wrońska-Nofer and Nofer, 1967). More direct evidence has been derived from clinical and necropsy studies. Although many reports are based on only a few cases and usually lack control groups, it seems that atherosclerosis, particularly of the cerebral arteries and the arteries of the lower limbs, is accelerated by CS $_{2}$ (Attinger, 1948; Nunziante Cesàro, 1953; Vigliani, 1954; Attinger, 1954; Vigliani and Pernis, 1955; von Rechenberg, 1957; Vigliani, 1961; Visconti, 1963; Gobbato, Sequi, and Turchetto, 1964; Navarro Martinez and Farina, 1969).

The possible effect of $\mathrm{CS}_{2}$ on the coronary arteries has received less attention, and the few larger series published, with one exception (Goto and Hotta, 1967), lack control groups. However, insofar as conclusions can be drawn from such studies, there seems to be an excess morbidity from coronary heart disease (CHD) among workers who have been poisoned or strongly overexposed or both (Crepet, Gobbato, and Scansetti, 1956; Vigliani, 1961; Gobbato et al., 1964; Goto and Hotta, 1967; Lilis, Gavrilescu, Moscovici, Teculescu, Roventa, Nestorescu, Senchea, and Pilat, 1968; Navarro Martinez and Farina, 1969). The excellent mortality study by Tiller, Schilling, and Morris (1968) confirmed that exposure to $\mathrm{CS}_{2}$ does affect the coronary system; it showed that the death rate from CHD in men exposed for 10 years or more in a British viscose rayon plant was two and a half times that of the other workers. The ratio of coronary deaths to other causes was also significantly higher among exposed workers in three other plants as compared to that of other workers of the same age, that of local men, or national figures derived from the Registrar General's tables. This excess mortality was more pronounced in the 1940s and declined towards the beginning of the 1960s, indicating a strong dependence on the intensity of exposure, which had decreased during this interval.

We have had the opportunity to study the coronary mortality and morbidity, and some factors known as coronary risk factors, among a group of 410 viscose rayon workers. All subjects were or had been employed in a Finnish viscose plant. They had been exposed for five years or more between 1941 and 1967 to $\mathrm{CS}_{2}$ and $\mathrm{H}_{2} \mathrm{~S}$. The intensity of exposure, which was rather high in the 1940s and 1950s, has declined during recent years to values around the Threshold Limit Value (TLV) of 20 ppm recom- mended by the American Conference of Governmental Industrial Hygienists (1968).

\section{Material and design}

The exposed group consisted of male workers in a Finnish viscose rayon plant, established in 1942. All men fulfilling the following criteria were included:

(1) age 25 to 64 years at the time of examination (1967/68);

(2) five years or more of continuous or interrupted exposure to $\mathrm{CS}_{2}$ in the most heavily polluted departments (see below) during any period between 1942 and 1967. This also includes workers who were no longer employed by the plant or who were working in 'clean' jobs at the time of examination;

(3) in addition, those who had died before reaching the age of 65 years were included, provided they met criteria (1) and (2).

The factory records from 1942 onwards were used for the selection of subjects fulfilling the above criteria. Since the records were satisfactory, the group is a complete tally of the relevant workers.

The total exposed group, including the 45 subjects who had died, comprised 410 men. Of these, 212 (211 examined, 1 unexamined) were working in polluted departments at the time of the study, but 81 had moved to 'clean' jobs within the plant. There were another 72 men who no longer worked at the plant; most of them were traced and 51 examined. Of the remaining 21 men in this group, 12 returned a letter saying that they were not willing to undergo the examination. Thus, only 9 men were not traced at all. In other words, $343(93.3 \%)$ of the 365 men who were known not to have died, were examined.

When the exposure times, recorded originally from the employee rolls, were checked against the subjects' own reports, 21 subjects were found with an exposure time of less than five but at least one year. These men were included in the study, however. The structure of the exposed group is given in Table 1 and Figure 1.

The material was analysed in two stages - the mortality in the whole group, and the present status of the survivors.

The status of the exposed group could have been affected by various kinds of selection at the entrance to the plant or during employment, by the preventive or therapeutic measures undertaken for or by those employed, and by the possible bias introduced by untraced cases. Men with markedly elevated blood pressure have usually been excluded at the pre-employment examination; they consequently do not appear in the present sample. Exclusions because of cardiac conditions have been very rare. All subjects receiving drug therapy or on prescribed diet were included in the sample. Subjects receiving sickness insurance compensation (11 men), and accordingly not working, were excluded since appropriate controls could not be found. Five men, for whom the indication for compensation was $\mathrm{CS}_{2}$ poisoning, however, were included. The evidence available on the health status of the 12 untraced cases who were known to be alive is not satisfactory.

Death certificates were obtained for 43 of the 45 exposed men who had died before reaching the age of 65 years 
TABLE 1

Structure and Coverage of the Exposed SAmple

\begin{tabular}{|c|c|c|c|c|c|c|c|c|c|c|c|c|}
\hline & & & & & & & \multicolumn{2}{|c|}{ Examined } & \multicolumn{2}{|c|}{ Not examined } & \multicolumn{2}{|c|}{ Total } \\
\hline & & & & & & & No. & $\%$ & No. & $\%$ & No. & $\%$ \\
\hline $\begin{array}{l}\text { Alive } \\
\text { Employed at plant } \\
\text { Left the plant } \\
\text { Total } \quad .\end{array}$ & $\begin{array}{l}\cdots \\
\cdots \\
\cdots\end{array}$ & $\begin{array}{l}\cdots \\
\cdots \\
\cdots\end{array}$ & $\begin{array}{l}\cdots \\
\cdots \\
\cdots\end{array}$ & $\begin{array}{l}\cdots \\
\cdots \\
\cdots\end{array}$ & $\begin{array}{l}\cdots \\
\cdots \\
\ldots\end{array}$ & $\begin{array}{l}\cdots \\
\cdots \\
\cdots\end{array}$ & $\begin{array}{r}292 \\
51 \\
343\end{array}$ & $\begin{array}{l}99 \cdot 7 \\
70 \cdot 8 \\
93 \cdot 3\end{array}$ & $\begin{array}{l}1 \\
21^{1} \\
22\end{array}$ & $\begin{array}{r}0 \cdot 3 \\
19 \cdot 2 \\
6 \cdot 7\end{array}$ & $\begin{array}{r}293 \\
72 \\
365\end{array}$ & $\begin{array}{l}100 \\
100 \\
100\end{array}$ \\
\hline $\begin{array}{l}\text { Dead } \\
\text { At start of examina } \\
\text { By } 2 \text { years after star }\end{array}$ & $\begin{array}{l}n \text { per } \\
\text { f ex }\end{array}$ & $\begin{array}{l}\text { d.. } \\
\text { inati }\end{array}$ & period & $\begin{array}{l}\ldots \\
\ldots\end{array}$ & $\begin{array}{l}. \\
\ldots\end{array}$ & 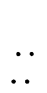 & $\begin{array}{r}43^{2} \\
5^{2}\end{array}$ & $\begin{array}{r}95 \cdot 6 \\
100.0\end{array}$ & $\underline{2}^{3}$ & $\begin{array}{l}4 \cdot 4 \\
0\end{array}$ & $\begin{array}{r}45 \\
5\end{array}$ & $\begin{array}{l}100 \\
100\end{array}$ \\
\hline
\end{tabular}

${ }^{1} 12$ persons were known to be alive at the time of the examination. No information was obtained about the remaining 9 subjects.

${ }^{2}$ Death certificate obtained

${ }^{3}$ Death certificate not obtained

between the end of the five-year initial exposure period and the time of the examination. Five additional deaths were recorded within the two years following the beginning of the examination period; the corresponding death certificates were obtained and the data were added to the analyses. Comparable mortality data, unfortunately, were not obtainable for the controls.

The exposed subjects who were alive and examined were matched individually with the same number of controls with histories of no or insignificant exposure ( $<1 / 2$ years' exposure to $\mathrm{CS}_{2}$ or other industrial poisons). They were selected from the employee rolls of a paper mill located in the same city, without any knowledge of the health of the control. The matching was based on the criteria of (1) maximal intra-pair age difference of \pm three years, (2) approximately the same birth district, ${ }^{1}$ and (3) approximate equality in the physical requirements of the work. The two groups were similar in occupational status. A minimum period of five years' continuous employment in the paper mill was also required. As the controls lived in the same environment as the exposed persons, systematic dissimilarities, such as the softness of their drinking water, seem unlikely. Pre-employment examinations made at the mill had criteria for exclusion similar to those made in the viscose rayon plant. Control subjects under drug therapy or on diet were not discarded in the matching. All controls were employed at the mill at the time of the examination. About 20 of the controls so selected did not attend the examination. In these cases a new control was selected as described above; no influence from the management on the selection was allowed.

1 This was done since interdistrict differences in cardiovascular mortality have been reported (Kannisto, 1947; Partanen, 1965). Some differences were observed in the cardiovascular status of the west-born and east-born controls. These and references to relevant literature have been given in detail elsewhere (Nordman, Partanen, and Hernberg, 1969).

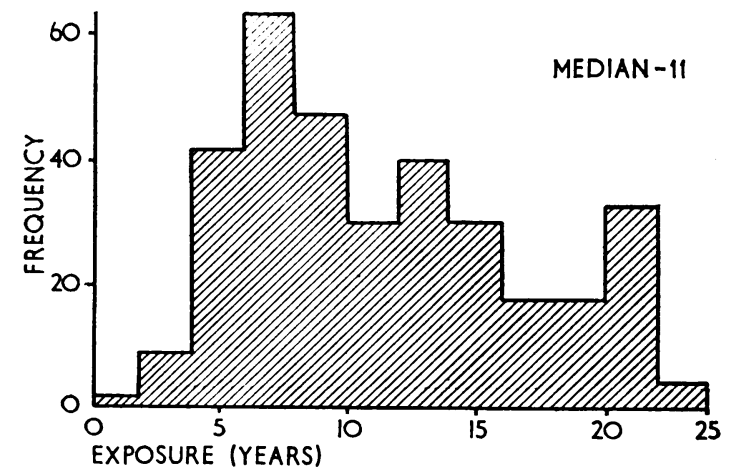

FIG. 1. Distribution of exposure times of the 343 men examined.

\section{Toxic environment}

The distribution of the men examined in terms of nature of work is given in Table 2, which also shows the polluted departments or tasks that have been considered as 'exposure' work. Workers who were in other jobs at the time of examination were classified according to their latest 'exposure' work. Owing to the policy adopted by the management, a large proportion of subjects has had variable job histories while under exposure.

The plant chemists had taken 5 to 10 minutes' air samples routinely 1 to 36 times per year from 10 to 40 different sites since 1945 . $\mathrm{CS}_{2}$ and $\mathbf{H}_{2} \mathrm{~S}$ concentrations were determined separately using a titrimetric xanthate method (Jacobs, 1949). The sampling was less systematic from 1945 to 1949 and more complete after this time. Altogether some 3000 measurements were available. The mean concentrations of $\mathrm{CS}_{2}+\mathrm{H}_{2} \mathrm{~S}$ in various locations are shown (Figs 2 to 5). The concentrations of $\mathrm{H}_{2} \mathrm{~S}$ were usually about one-tenth of those of $\mathrm{CS}_{2}$.

An index of exposure dosage was calculated for every exposed subject from his work history using the $\mathrm{CS}_{2}+\mathrm{H}_{2} \mathrm{~S}$ 
TABLE 2

\section{Distribution OF EXPOSED GROUP ACCORDING TO TYPE OF WORK}

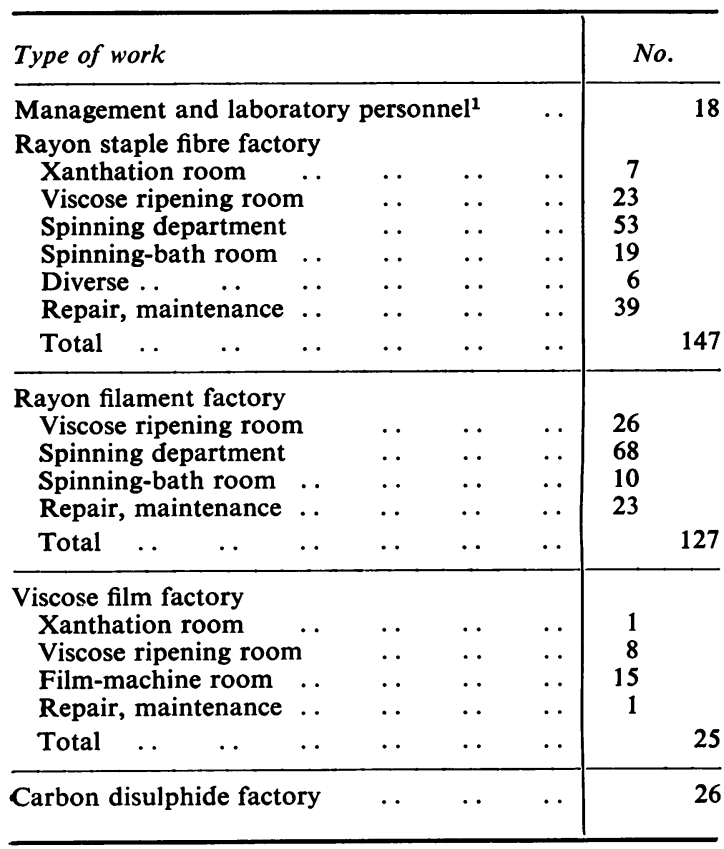

${ }^{1}$ Engineers and chemists spending at least half their time in polluted departments. When their exposure index was calculated, the exposure time was divided by 2 . determinations referred to above. The index (D) was calculated from the formula:

$$
\mathrm{D}=\frac{\Sigma_{\mathrm{i}} \Sigma_{\mathrm{j}} \mathrm{f}_{\mathrm{ij}} \overline{\mathrm{x}}_{\mathrm{ij}}}{12}
$$

where

$f_{i j}=$ number of months worked at department ${ }_{i}$ during year $j$

$\overline{\mathbf{x}}_{\mathbf{1 j}}=$ annual arithmetic mean of the $\mathrm{CS}_{2}+\mathrm{H}_{2} \mathrm{~S}$ concentration (ppm in the air of department ${ }_{1}$ for year $\mathrm{j}$ ).

This is an approximate measure of personal exposure history where time and intensity of exposure have both been taken into account.

The validity of the index can be criticized mainly from three major viewpoints. Firstly, the measurements have been made comparatively infrequently and not necessarily during representative conditions or from representative sites. Secondly, the movements of the workers during the work shift may result both in periods with slight or no exposure, and in periods with very high exposure, as, for instance, during the repair and maintenance of machines. Thirdly, a 25-year retrospective analysis of the whereabouts of the workers cannot be very exact.

\section{Methods}

A questionnaire covering birthplace, migration history, smoking habits, physical activity, previous and current diseases and present medication was prepared especially for this study and was mailed to each person. Coronary history was obtained by using a WHO questionnaire (World Health Organization, 1963), which allows for the classification of possible symptoms according to the severity and probability of coronary aetiology.

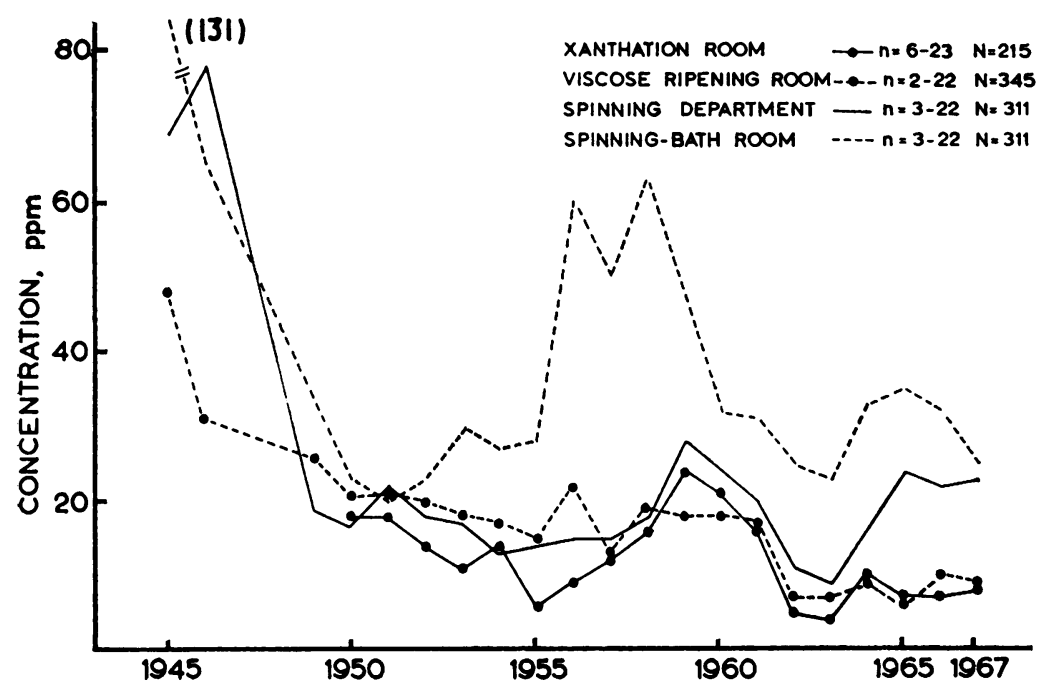

FIG. 2. Concentration of $\mathrm{CS}_{2}+\mathrm{H}_{2} \mathrm{~S}$ (arithmetic means) in the air of the rayon staple fibre factory: $n=$ number of samples per year; $N=$ total number of samples 1945-67. 


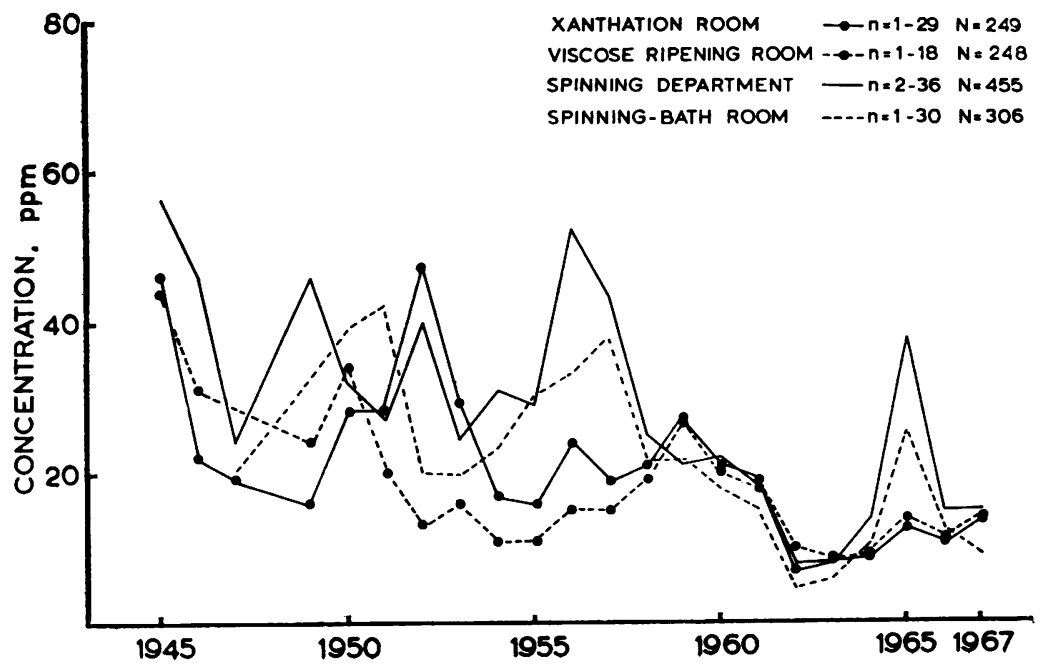

FIG. 3. Concentration of $\mathrm{CS}_{2}+\mathrm{H}_{2} \mathrm{~S}$ (arithmetic means) in the air of the rayon filament factory: $\mathrm{n}=$ number of samples per year; $\mathrm{N}=$ total number of samples 1945-67.

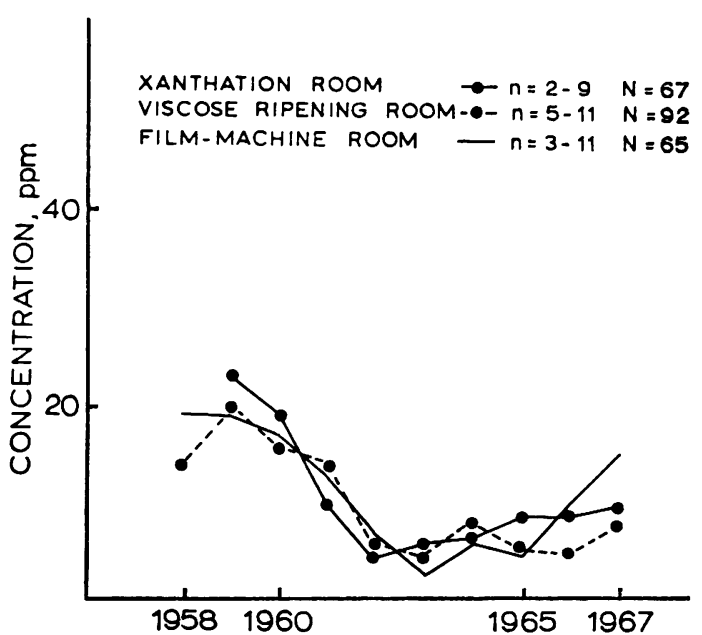

FIG. 4. Concentration of $\mathrm{CS}_{2}+\mathrm{H}_{2} \mathrm{~S}$ in the viscose film factory: $\mathbf{n}=$ number of samples per year; $\mathbf{N}=$ total number of samples 1945-67.

Blood pressure was measured by one member of the team (S.H.) using a mercury column with wrap-around cuffs $(14 \times 65 \mathrm{~cm})$ and a stethoscope. The same instruments were used throughout the study. The measurements were made at room temperature after the subject had been resting for at least 15 minutes. With the subject in the sitting position, two successive recordings were made from the right arm, the mercury column being allowed to reach zero before the beginning of the second measurement. The diastolic readings were made when Korotkoff's sounds disappeared.

Electrocardiographic recordings were obtained using an ink-jet direct-writing 4-channel electrocardiograph, Mingograph 34 (Elema - Schönander), at a paper speed of $50 \mathrm{~mm} /$ second. Each channel was tested every morning and the calibration was carefully controlled.

After at least 30 minutes of abstinence from eating, smoking and physical activity a 12-lead ECG was recorded with the subject lying down. A standardized exercise test using a Monark bicycle ergometer was then performed. The exercise lasted 4 minutes with a constant work load. Subjects under 50 years of age were loaded with 8.8 $\mathrm{kJ} / \mathrm{min}(900 \mathrm{kpm} / \mathrm{min})$, those aged between 50 and 59 years with $5.9 \mathrm{~kJ} / \mathrm{min}(600 \mathrm{kpm} / \mathrm{min})$ and subjects 60 years of age or more worked at $4.4 \mathrm{~kJ} / \mathrm{min}(450 \mathrm{kpm} / \mathrm{min})$. All men with manifest heart disease, a blood pressure exceeding $200 / 110 \mathrm{~mm} \mathrm{Hg}$, a resting ECG indicating probable previous infarction, left bundle-branch block, atrial fibrillation or flutter, or other serious changes were excluded from the exercise test. The work load was reduced if minor findings were present in the resting ECG or if there was a history of angina. The exercise test was not completed if angina, severe dyspnoea or claudication appeared.

During exercise the chest-head leads $\mathrm{CH}_{3-6}$ (Holmgren and Strandell, 1961) were recorded at $1,2,3$ and $3 \frac{1}{2}$ minutes. A 12-lead ECG was recorded immediately (30 to 60 seconds) after the completion of the exercise test with the subject lying down.

The ECGs were classified according to the Minnesota code (Blackburn, Keys, Simonson, Rautaharju, and 


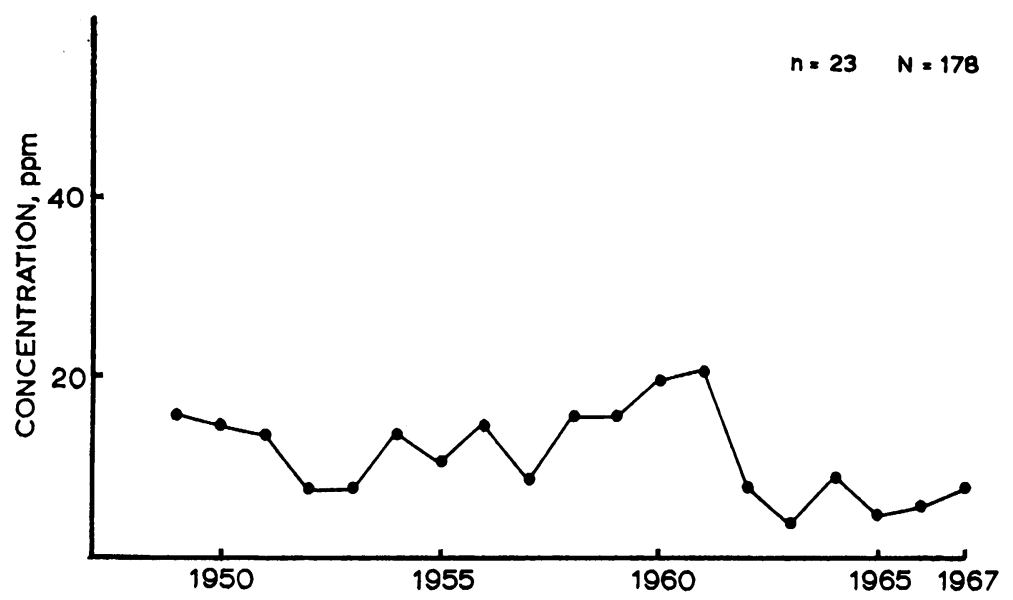

FIG. 5. Concentration of $\mathrm{CS}_{2}+\mathrm{H}_{2} \mathrm{~S}$ in the air of the $\mathrm{CS}_{2}$ factory: $\mathrm{n}=$ number of samples per year; $\mathrm{N}=$ total number of samples $1945-67$.

Punsar, 1960). The most marked pathological change in any of the post-exercise recordings was coded (e.g., the deepest S-T depression or T-inversion). All records were read twice by the same person (C-H.N.). To attain a blind reading, each record was supplied with a code number, all other identifications being removed. In cases where the first and second readings varied, the final conclusion was arrived at by discussion with another reader.

The coronary findings were also classified according to the criteria proposed by Epstein, Ostrander, Johnson, Payne, Hayner, Keller, and Francis (1965); the postexercise Minnesota codes XI and XII were added to group III of this classification. In addition, the P, PR, Q, QT durations and the $T$ amplitude were measured.

Maximal oxygen uptake was estimated indirectly according to the method of Åstrand and Ryhming (1954).

Antero-posterior and lateral $100 \times 100 \mathrm{~mm}$ radiographs of the chest were taken with a Philips $x$-ray apparatus (200 mA, $125 \mathrm{kV}$, Odelca camera, $100 \mathrm{~mm})$. The interpretation of the radiographs was made by an experienced radiologist. Heart size was calculated from the following formula:

$$
\mathrm{V}=\text { k.a.b.c, }
$$

where $a, b$, and $c$ are heart diameters and $k$ is an empirical coefficient which is specific for each camera and calculated from the antero-posterior and lateral picture-enlarging coefficients.

\section{Statistical methods}

The results were tabulated as comparisons between the exposed and the controls at four levels: total exposed group, spinners ( $\geqslant 2$ years in the spinning rooms), those exposed for 15 years or more, and those with an exposure dosage index exceeding the mean value of the whole group $(D \geqslant 245)$. The individual matching was taken into account in most comparisons when testing the significance of the 'effects'. The sign test (binomial or $\chi^{2}$ approximation) was used for testing the qualitative paired comparisons, and the t-test for the quantitative paired comparisons. Mortality has been analysed in the total exposed group using official mortality statistics for the total urban male population for comparison. ${ }^{1}$ Life table analysis was carried out for all causes of death (survival rate comparison) and assessment of the proportionate distribution of the 48 deaths.

\section{Assessment of coronary risk factors}

Care was taken to eliminate as many as possible of the biases caused by dissimilarities between the groups with regard to coronary risk factors. Some factors were equalized by the selection of the controls (age, birth district, similarity of job and professional status), others were explored with the aid of a detailed questionnaire, and some were measured at the examination. The risk factors can be divided into two groups with regard to possible dependence on $\mathrm{CS}_{2}$. Independent factors such as smoking habits and leisure time physical activity are described in this section, while those possibly influenced by exposure, for example blood pressure, are reported in the results or, in case of blood lipids and blood sugar, published as a separate article (Hernberg, Nordman, Partanen, Christiansen, and Virkola, in press).

Table 3 shows a comparison between some important background variables of the two groups. The small differences seen hardly cause any significant bias. We considered the cumbersome task of a detailed inquiry into dietary habits unnecessary; there was no apparent reason for assuming systematic dietary differences.

The validity of measuring habitual physical activity by questionnaire methods is probably low (Oja and Partanen, unpublished results). Therefore, we also used the indirectly calculated maximum oxygen uptake capacity ( $\AA$ strand and Ryhming, 1954) as a measure of the physical fitness. The slightly higher uptake capacity found

${ }^{1}$ No tables for the occupationally active population are available. 
TABLE 3

Some Background Variables of the Exposed and Control Groups

\begin{tabular}{|c|c|c|c|c|c|c|c|c|c|c|c|c|c|c|}
\hline & & & & & & & & & & & & & $\begin{array}{l}\text { Exposed } \\
\quad(343)\end{array}$ & $\begin{array}{c}\text { Controls } \\
\text { (343) }\end{array}$ \\
\hline $\begin{array}{l}\text { Age }(y r) \\
\text { Mean } \\
\text { SD . }\end{array}$ & $\begin{array}{l}\cdots \\
\cdots\end{array}$ & $\begin{array}{l}\cdots \\
\cdots\end{array}$ & $\begin{array}{l}\cdots \\
\cdots\end{array}$ & $\begin{array}{l}\cdots \\
\cdots\end{array}$ & $\begin{array}{l}\cdots \\
\cdots\end{array}$ & $\begin{array}{l}\cdots \\
\cdots\end{array}$ & $\begin{array}{l}\cdots \\
\cdots\end{array}$ & $\begin{array}{l}\cdots \\
\cdots\end{array}$ & $\begin{array}{l}\cdots \\
\cdots\end{array}$ & $\begin{array}{l}\cdots \\
\cdots\end{array}$ & $\begin{array}{l}\cdots \\
\cdots\end{array}$ & $\begin{array}{l}\cdots \\
\cdots\end{array}$ & $\begin{array}{r}45 \cdot 4 \\
9 \cdot 0\end{array}$ & $\begin{array}{r}45 \cdot 4 \\
9 \cdot 1\end{array}$ \\
\hline \multicolumn{13}{|c|}{$\begin{array}{l}\text { Cigarettes smoked per day, } \\
\% \text { distribution }\end{array}$} & \multirow{3}{*}{$\begin{array}{r}45 \cdot 4 \\
9 \cdot 9 \\
24 \cdot 2 \\
17 \cdot 2 \\
1 \cdot 5 \\
0 \cdot 3 \\
1 \cdot 5 \\
100 \cdot 0\end{array}$} & \multirow{3}{*}{$\begin{array}{r}51 \cdot 3 \\
9 \cdot 0 \\
24 \cdot 2 \\
12 \cdot 8 \\
1 \cdot 2 \\
\overline{1 \cdot 5} \\
100 \cdot 0\end{array}$} \\
\hline $\begin{array}{l}0 \\
1-9 \\
10-19 \\
20-29 \\
30-39 \\
40- \\
\text { No inform }\end{array}$ & $\begin{array}{l}\cdots \\
\ldots \\
\ldots \\
\ldots \\
\cdots \\
\text { ation }\end{array}$ & $\begin{array}{l}\ldots \\
\ldots \\
\cdots \\
\cdots \\
\cdots \\
\cdots \\
\cdots\end{array}$ & $\begin{array}{l}\ldots \\
\ldots \\
\cdots \\
\cdots \\
\cdots \\
\cdots\end{array}$ & $\begin{array}{l}\ldots \\
\ldots \\
\ldots \\
\cdots \\
\cdots \\
\cdots\end{array}$ & $\begin{array}{l}\ldots \\
\cdots \\
\cdots \\
\cdots \\
\cdots \\
\cdots \\
\cdots\end{array}$ & $\begin{array}{l}\ldots \\
\ldots \\
\ldots \\
\ldots \\
\ldots \\
\cdots\end{array}$ & $\begin{array}{l}\ldots \\
\ldots \\
\ldots \\
\ldots \\
\ldots \\
\ldots\end{array}$ & $\begin{array}{l}\ldots \\
\ldots \\
\cdots \\
\ldots \\
\ldots \\
\cdots\end{array}$ & $\begin{array}{l}\ldots \\
\ldots \\
\ldots \\
\ldots \\
\cdots \\
\cdots\end{array}$ & $\begin{array}{l}\ldots \\
\cdots \\
\cdots \\
\cdots \\
\cdots \\
\cdots\end{array}$ & $\begin{array}{l}. \\
\cdots \\
\cdots \\
\cdots \\
\cdots \\
\cdots \\
\cdots\end{array}$ & $\begin{array}{l}\ldots \\
\cdots \\
\cdots \\
\cdots \\
\cdots \\
\cdots \\
\cdots\end{array}$ & & \\
\hline Total .. & . & . & . & . & . & . & . & . & . & . & .. & .. & & \\
\hline \multicolumn{13}{|c|}{$\begin{array}{l}\text { Leisure-time physical activity, } \\
\% \text { distribution }\end{array}$} & \multirow{3}{*}{$\begin{array}{r}12 \cdot 8 \\
31 \cdot 8 \\
32 \cdot 1 \\
19 \cdot 2 \\
4 \cdot 1 \\
100 \cdot 0\end{array}$} & \multirow{3}{*}{$\begin{array}{r}9 \cdot 9 \\
23 \cdot 9 \\
37 \cdot 3 \\
24 \cdot 8 \\
4 \cdot 1 \\
100 \cdot 0\end{array}$} \\
\hline $\begin{array}{l}\text { None } \\
\text { Seldom } \\
\text { Once a we } \\
\text { Once a day } \\
\text { No inform }\end{array}$ & $\begin{array}{l}\cdots \\
. \ddot{k} \\
\text { lation }\end{array}$ & $\begin{array}{l}. \\
\cdots \\
\cdots \\
\cdots \\
\cdots\end{array}$ & $\begin{array}{l}\ldots \\
\cdots \\
\cdots \\
\cdots\end{array}$ & $\begin{array}{l}\ldots \\
\cdots \\
\cdots \\
\cdots \\
\cdots\end{array}$ & $\begin{array}{l}\ldots \\
\cdots \\
\cdots \\
\cdots \\
\cdots\end{array}$ & $\begin{array}{l}\ldots \\
\cdots \\
\cdots \\
\ldots\end{array}$ & $\begin{array}{l}\ldots \\
\cdots \\
\cdots \\
\cdots\end{array}$ & $\begin{array}{l}\ldots \\
\ldots \\
\ldots \\
\ldots \\
\cdots\end{array}$ & $\begin{array}{l}\ldots \\
\cdots \\
\cdots \\
\cdots\end{array}$ & $\begin{array}{l}\ldots \\
\cdots \\
\cdots \\
\cdots \\
\cdots\end{array}$ & $\begin{array}{l}\ldots \\
\cdots \\
\cdots \\
\cdots \\
\cdots\end{array}$ & $\begin{array}{l}\ldots \\
\cdots \\
\cdots \\
\cdots \\
\ldots\end{array}$ & & \\
\hline Total & . & . & . & .. & . & .. & .. & . & .. & .. & . & . & & \\
\hline \multicolumn{13}{|c|}{ Relative body weight ${ }^{1}$} & \multirow[b]{2}{*}{$\begin{array}{r}116 \cdot 2 \\
14 \cdot 3\end{array}$} & \multirow[b]{2}{*}{$\begin{array}{r}117 \cdot 5 \\
14 \cdot 5\end{array}$} \\
\hline $\begin{array}{l}\text { Mean } \\
\text { SD .. }\end{array}$ & $\begin{array}{l}. . \\
\cdots\end{array}$ & $\begin{array}{l}\cdots \\
\cdots\end{array}$ & $\begin{array}{l}\cdots \\
\cdots\end{array}$ & $\begin{array}{l}\cdots \\
\cdots\end{array}$ & $\begin{array}{l}\cdots \\
\cdots\end{array}$ & $\begin{array}{l}\cdots \\
\cdots\end{array}$ & $\begin{array}{l}\cdots \\
\cdots\end{array}$ & $\begin{array}{l}\cdots \\
\cdots\end{array}$ & $\begin{array}{l}\cdots \\
\cdots\end{array}$ & $\begin{array}{l}\ldots \\
\cdots\end{array}$ & $\begin{array}{l}\cdots \\
\cdots\end{array}$ & $\begin{array}{l}\cdots \\
\cdots\end{array}$ & & \\
\hline $\begin{array}{c}\text { No. of subjec } \\
\text { Antihypert } \\
\text { Digitalis } \\
\text { Sedatives } \\
\text { Glyceryl n }\end{array}$ & $\begin{array}{l}\text { cts pre } \\
\text { tensive } \\
\ldots \\
\text {. } \\
\text { itrate o }\end{array}$ & $\begin{array}{l}\text { sentl } \\
\text { dru } \\
\cdots \\
\therefore \\
\text { r re }\end{array}$ & $\begin{array}{l}\text { and } \\
\text { and } \\
\ldots \\
\text { ed }\end{array}$ & $\begin{array}{l}\text { rug } \\
\text { diur } \\
\ldots \\
\ldots \\
\text { pou }\end{array}$ & $\begin{array}{l}\text { rap } \\
\text { cs } \\
\ldots \\
\cdots\end{array}$ & $\begin{array}{l}\cdots \\
\cdots \\
\ldots\end{array}$ & $\begin{array}{l}\cdots \\
\cdots \\
\cdots\end{array}$ & $\begin{array}{l}\cdots \\
\cdots \\
\cdots \\
\cdots\end{array}$ & $\begin{array}{l}\ldots \\
\cdots \\
\cdots\end{array}$ & $\begin{array}{l}\cdots \\
\cdots \\
\cdots \\
\cdots\end{array}$ & $\begin{array}{l}\cdots \\
\cdots \\
\cdots \\
.\end{array}$ & $\begin{array}{l}\cdots \\
\cdots \\
\cdots \\
\cdots\end{array}$ & $\begin{array}{r}7 \\
1 \\
11 \\
13\end{array}$ & $\begin{array}{r}6 \\
3 \\
13 \\
8\end{array}$ \\
\hline
\end{tabular}

${ }^{1}$ The relative body weight was calculated by expressing the actual weight as percentage of the ideal weight (Metropolitan Life Insurance Company Statistical Bulletin, 40, 1959)

in the exposed group (Table 4) is probably too small to introduce any significant bias.

TABLE 4

Predicted Maximal Oxygen Uptake (mean and standard deviation)

\begin{tabular}{|c|c|c|c|c|c|}
\hline & & & & Exposed & Controls \\
\hline $\begin{array}{c}\operatorname{Max} \operatorname{Vo}_{2}(1 / \mathrm{min} \\
\operatorname{Mean} \quad . \\
\text { SD } \\
\text { No. of pairs }\end{array}$ & $\begin{array}{l}\cdots \\
\cdots \\
\cdots\end{array}$ & $\begin{array}{l}\cdots \\
\cdots \\
\cdots\end{array}$ & $\begin{array}{l}\cdots \\
\cdots \\
\cdots\end{array}$ & $\begin{array}{l}2 \cdot 63 \\
0 \cdot 58\end{array}$ & $\begin{array}{l}2 \cdot 57 \\
0.51\end{array}$ \\
\hline $\begin{array}{cc}\mathrm{Max} \mathrm{Vo}_{2}(\mathrm{ml} / \mathrm{kg} \\
\text { Mean } \quad . \\
\text { SD } \\
\text { No. of pairs }\end{array}$ & $\begin{array}{l}\min ) \\
\ldots \\
\ldots \\
\ldots\end{array}$ & $\begin{array}{l}\cdots \\
\ldots \\
\ldots\end{array}$ & $\begin{array}{l}\cdots \\
\cdots \\
.\end{array}$ & $\begin{array}{r}35 \cdot 2 \\
8 \cdot 5\end{array}$ & $\begin{array}{r}34 \cdot 2 \\
7 \cdot 4\end{array}$ \\
\hline
\end{tabular}

No. of pairs with full information

\section{Results}

\section{Mortality}

Life table analysis, performed as a comparison between survival rates for the 30- to 54-year-old subgroup of the exposed sample and for the total urban male population in Finland did not yield any essential information. The survival rate for the exposed group was consistently higher than that for the male population alive at 30 during 1951-55. This is most likely due to selection operating in any industrial population. In most cases it results in an increase of survival. The results should therefore not be interpreted as no hazard attributable to the exposure.

Twenty-five $(52 \%)$ of the 48 deaths were recorded as coronary (codes 420 to 422 in the international classification, 1955 revision) according to the coded death certificates. The expected number of coronary deaths, adjusted for age and year of death and based on official statistics for the general male population, 
was calculated to be $15 \cdot 2$ The two-tailed cumulative binomial gave the risk level of incorrect conclusion of two different populations as 0.0018 . In other words, the proportion of coronary deaths out of all deaths was higher than expected on the basis of general mortality statistics, adjusted for age and year of death.

\section{History of infarction}

In all four groupings a history of myocardial infarction (verified and not verified, Table 5) was slightly more frequent among the controls than among the exposed. However, no P value less than 0.20 was observed.

\section{Chest pain}

The prevalence of reported chest pain, classified into typical, probable, and possible angina, is shown in Table 6 . The $6 \%$ difference in the prevalence of positive angina between the total exposed and control group was significant within $0.01<P<0.025$, the exposed displaying higher prevalence. The same magnitude of difference was noted between those with a dosage index exceeding $245(245=$ mean value of whole group) and their respective controls. However, the $P$ value exceeded $0 \cdot 20$. The spinners also reported angina more frequently than did their controls $(0 \cdot 10<P<0 \cdot 20)$.

\section{Blood pressure}

The clearest differences in the clinical data were noted for blood pressure (Table 7). An average 4 to 6 $\mathrm{mm} \mathrm{Hg}$ difference was calculated in all 12 subtables, the exposed persons displaying higher values. The significance levels for this were, in most cases, relatively high. In order to find out a possible dependence on exposure time, the intra-pair differences between the blood pressure of the exposed

TABLE 5

REPORTED HISTORY OF MYOCARDIAL INFARCTION (\%)

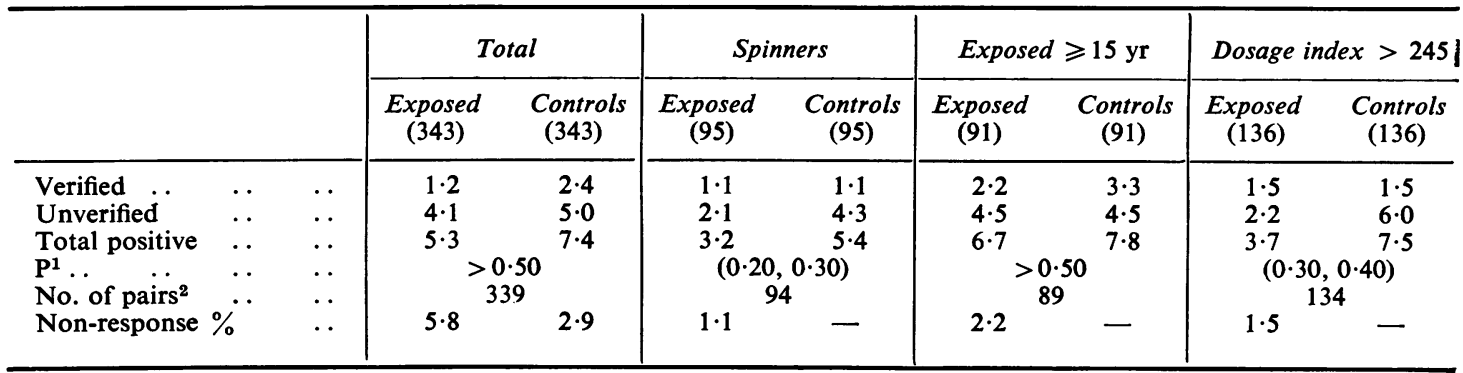

${ }^{1}$ Based on the binomial distribution or $\chi^{2}$ tests, corrected for continuity. All positives combined for testing.

${ }^{2}$ No. of pairs with full information. The percentage and risk levels are based on this total.

TABLE 6

Prevalence (\%) of Reported Chest Pann, Classified into Categories of Angina

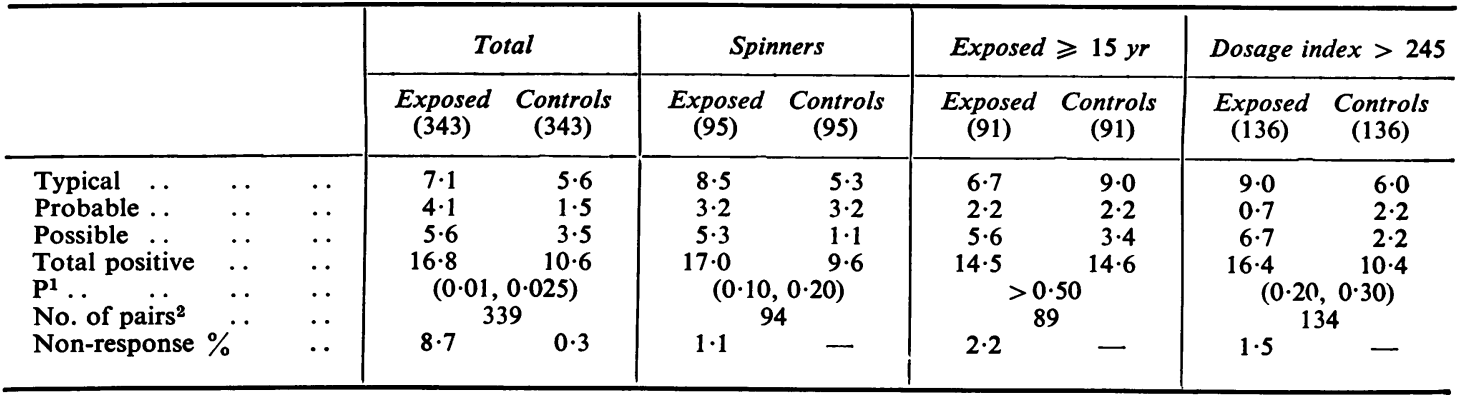

${ }^{1}$ Based on the binomial distribution or $\chi^{2}$ tests, corrected for continuity. All positives combined for testing. ${ }^{2}$ No. of pairs with full information. The prevalence estimates and risk levels are based on this total. 
TABLE 7

Blood Pressure (Mean and Standard Deviation)

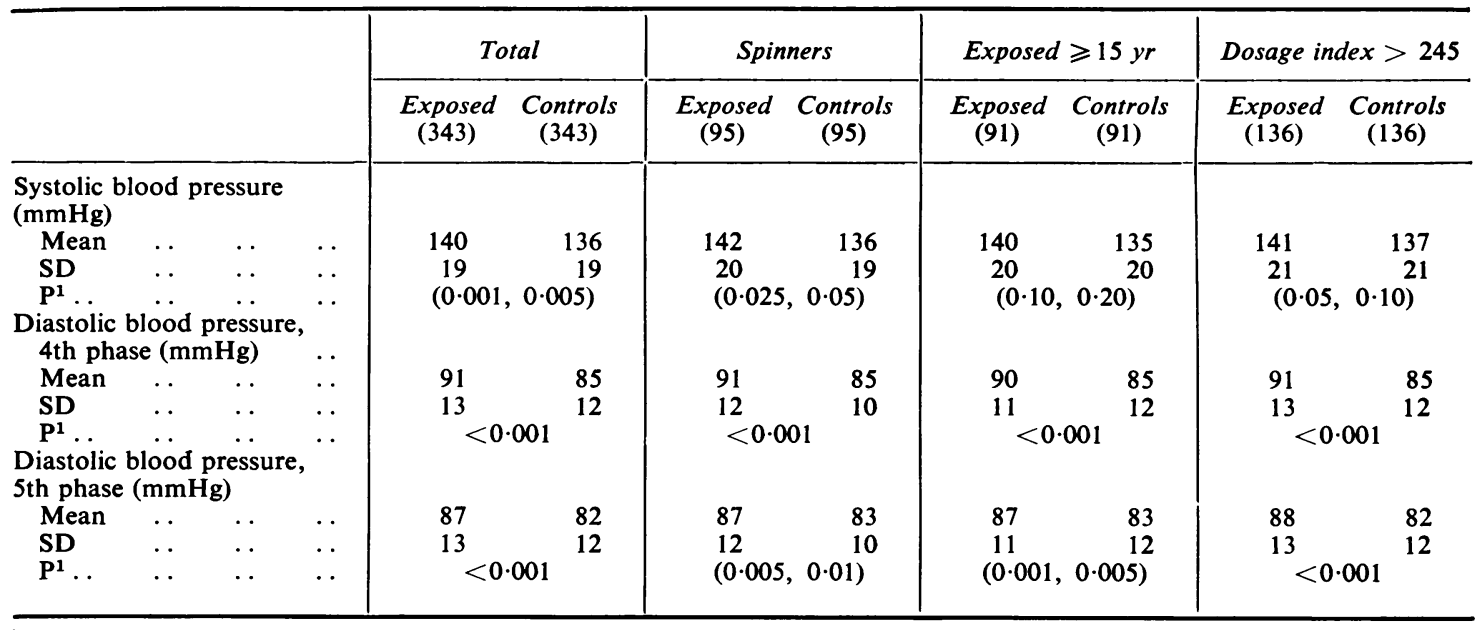

${ }^{1}$ Based on two-tailed t-test for mean intra-pair difference $=0$

and their matched pairs were correlated with the exposure times of the former. The calculated correlation coefficients were very low $(0.01$ for systolic; 0.00 and -0.01 for the two diastolic readings).

\section{ECG findings}

Results from ECG findings are given in Table 8. No great differences were noted. Three of the 20 significance tests revealed an 'effect' demonstrable with $0 \cdot 10<\mathrm{P}<0.20$ but none with a higher confidence. These three referred to code $\mathrm{XI}_{1-3},{ }_{5-7}$ (post-exercise S-T depressions) of those exposed for at least 15 years, code $\mathrm{XII}_{1-6}$ (post-exercise $\mathrm{T}$-wave inversions) of the total group, and the same code for those with a dosage index exceeding 245 . The exposed persons showed higher prevalences than did the controls. The same confidence level was noted for the higher prevalence of the 'coronary-

TABLE 8

Prevalence (\%) of Selected ECG Findings according to the 'Minnesota Code'

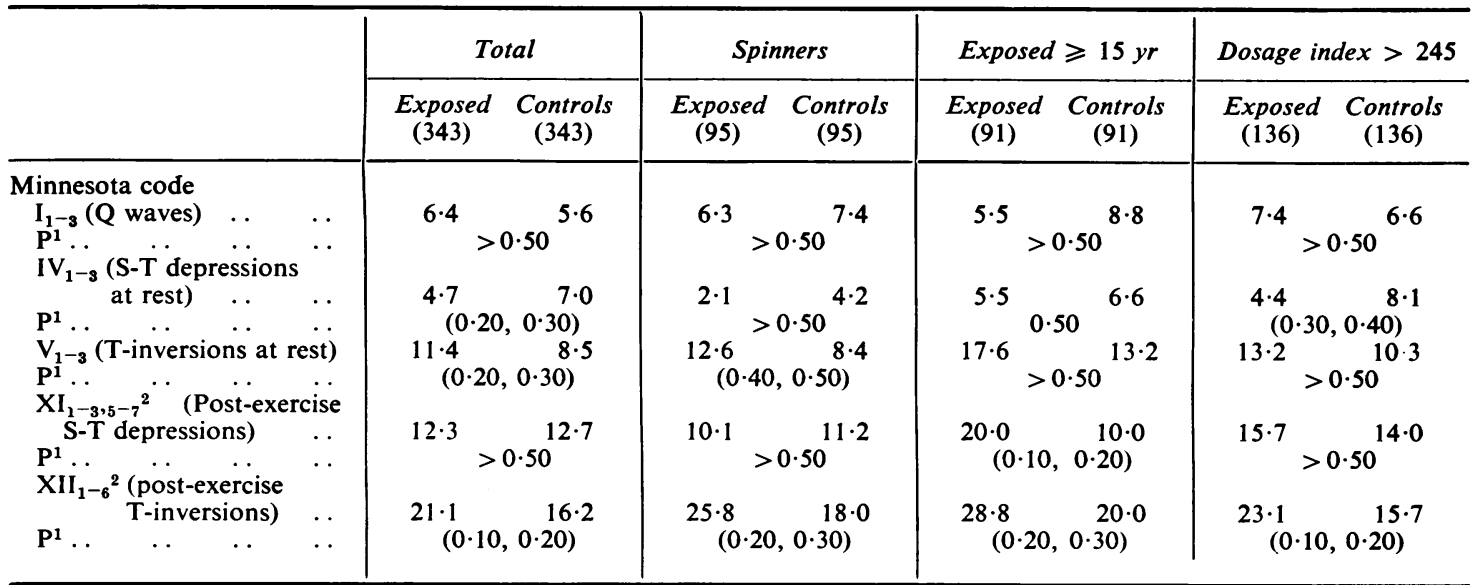

${ }^{1}$ Based on the McNemar test, corrected for continuity

${ }^{2}$ Prevalence and risk levels calculated from the total number of pairs having both members to take the exercise test. The numbers are 308 (total), 89 (spinners), 80 (exposed $\geq 15 \mathrm{yr}$ ), 121 (dosage index $>245$ ) 
positive' findings of the exposed group, as classified by the Epstein system (Table 9).

The prevalence of positive findings according to the Minnesota classes listed in Table 8 were also calculated only for those who were exposed at the time of examination, as well as for the presently exposed spinners and their pairs. No statistically or practically significant differences were found. This was also true for the mean $P, P R, Q$, and QT durations and the $T$ amplitude for the total exposed and control groups.

\section{X-ray data}

The comparisons between the exposed and the controls with regard to heart volume, left ventricular hypertrophy and generally enlarged heart are shown

TABLE 9

Prevalence of 'Coronary' ECG Findings ACCORDING TO THE 'EPSTEIN Classification' (TOTAL Groups)

\begin{tabular}{llll|cr}
\hline & & & & $\begin{array}{c}\text { Exposed } \\
(343)\end{array}$ & $\begin{array}{c}\text { Controls } \\
(343)\end{array}$ \\
\hline I (grave) &. &. &.. & $5 \cdot 5$ & $4 \cdot 7$ \\
II (moderate) & &. & $\ldots$ & $2 \cdot 3$ & $1 \cdot 5$ \\
III (mild) &. &. &.. & $22 \cdot 4$ & $19 \cdot 0$ \\
I+ II + III &. &. &.. & $30 \cdot 2$ & $25 \cdot 2$ \\
P1 &.. &. &.. & \multicolumn{2}{|c}{$(0 \cdot 10,0 \cdot 20)$} \\
\hline
\end{tabular}

${ }^{1}$ Based on $\chi^{2}$ for fourfold table (all positive combined) with Yates' correction for continuity in Table 10. Because of low prevalences, the two latter findings were tabulated for the total groups only. The mean heart volume was higher for the exposed group, as were the prevalences of left ventricular hypertrophy and generally enlarged heart. The differences may well depend on chance.

\section{Discussion}

As prolonged overexposure to $\mathrm{CS}_{2}$ may cause generalized atherosclerosis (Vigliani, 1961), it is not surprising that several studies indicate that the coronary system is also involved. Most of these deal with $\mathrm{CS}_{2}$ poisoning, or at least with severe over-exposure. Crepet and his colleagues (1956) found coronary heart disease in 4 patients out of 10, Vigliani (1961) reported 4 cases of infarction among 43 severely poisoned patients with generalized atherosclerosis, and Gobbato and his colleagues (1964) found a high prevalence of coronary heart disease (15 cases out of 61). Navarro Martinez and Farina (1969) found ECG changes indicative of coronary heart disease in $16 \%$ of 75 patients with $\mathrm{CS}_{2}$ poisoning. Taccola and Majeron (1964) studied 91 workers exposed to carbon disulphide. Most of them were in hospital for the investigation of the possible role of $\mathrm{CS}_{2}$ in the aetiology of a disease already manifest (peripheral vascular disease, nephropathy, retinopathy, neurological disorders, etc.). Others were studied in connection with a routine examination or minor surgery. However, the group cannot be considered as suitable for a prevalence study as the presence of vascular disease was one of

\section{TABLE 10}

Heart Volume (Mean and Standard Deviation) and Prevalence of Left Ventricular HYPERTROPHY AND OF GeNERALly ENLARGEd HeART.

(Only pairs with both members examined radiologically are included.)

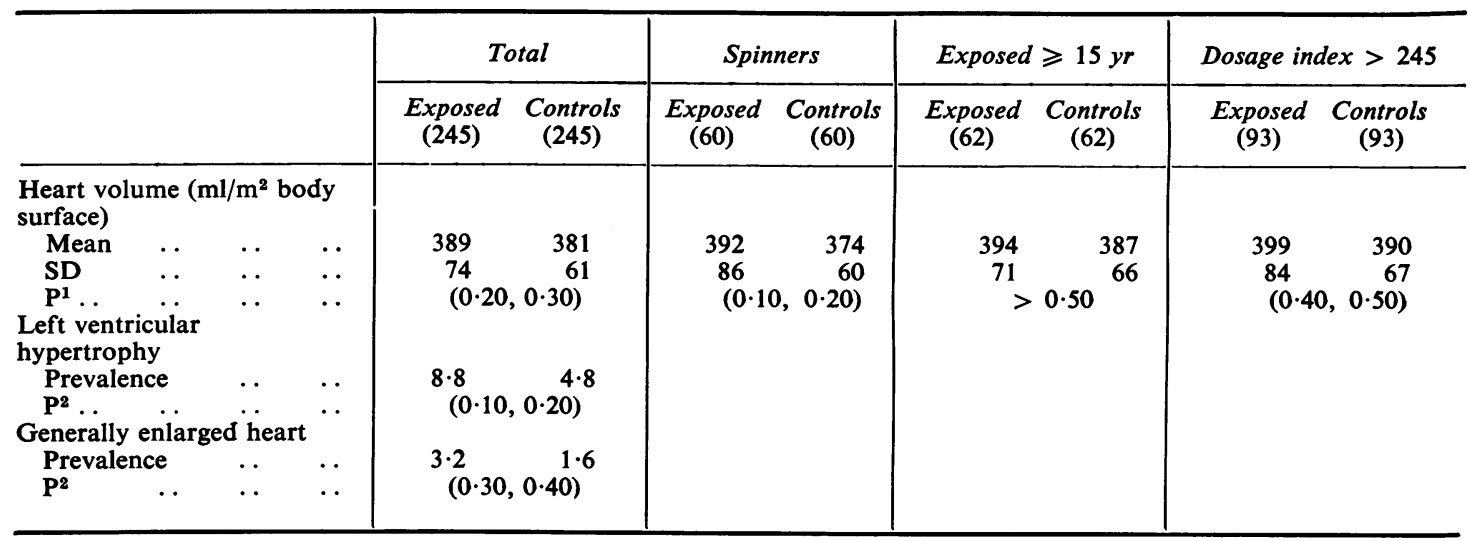

'Based on two-tailed $t$-test for mean intra-pair difference $=0$

2Based on the McNemar test, corrected for continuity 
the criteria for inclusion. Among this selected group they found 46 pathological ECGs. All these studies lack control groups, which limits their value, but the frequencies reported are so high that one is apt to believe that heavy overexposure to $\mathrm{CS}_{2}$ really is an aetiological factor of coronary heart disease.

So far as we know, there are only three studies concerning coronary heart disease among workers exposed to $\mathrm{CS}_{2}$ concentrations around the TLV value of $20 \mathrm{ppm}$ (American Conference of Governmental Industrial Hygienists, 1968). Goto and Hotta (1967) made an extensive study of 762 Japanese viscose rayon workers and compared the results with those obtained from 270 controls of the same age. Among other differences, they found significantly more post-exercise S-T depressions in the exposed group. Lilis and her colleagues (1968) studied 138 rayon workers. Out of them, $7.9 \%$ had post-exercise ECG readings which the authors interpreted as indicative of coronary heart disease. The lack of a control group, however, makes the interpretation of their results somewhat difficult. The most convincing proof of the significance of $\mathrm{CS}_{2}$ in the aetiology of coronary heart disease comes from the mortality study published by Tiller and his colleagues (1968), already mentioned in the introduction. However, as those authors themselves point out, the most distinct excess mortality occurred during a period of high-intensity exposure, while the difference became less clear towards the end of the observation period when exposure was lower.

As coronary heart disease is a common condition among middle-aged men, care must be taken to avoid biases when the role of $\mathrm{CS}_{2}$ as an aetiological factor is studied. The selection of the control group is probably the most critical factor in the present design. The efforts to avoid biases in this study as well as the inevitable failures in some respects have already been mentioned, but a short summary may be needed.

The individual matching design used eliminated bias caused by differences in age, birth district, social status, nature of work, and living area. Smoking habits, leisure time physical activity, physical fitness, obesity, and drug therapy were checked at the examination; the slight differences found were hardly of such a magnitude as to introduce bias. Possible differences in blood pressure, blood lipids, blood sugar, and plasma creatinine were considered to be effects of exposure; they are, therefore, not considered in this context. Among the factors that proved impossible to control was the unknown extent of selection at the entrance to employment. A certain degree of self-selection is probable, but it is hard to tell in which direction it might influence the results. A selection made on the basis of the pre-employment examination at least excludes persons with manifest hypertension or severe 2 cardiac conditions; to what extent quantitative differences between the two plants exist is difficult to assess, but it may, perhaps, be assumed that the screening has been more strict in the viscose rayon plant. This bias is probably small due to the low frequency of such disorders. More serious bias is introduced by self-selection during employment. Although only 9 men out of the total of 51 examined who had moved away reported that health reasons were the cause for leaving the job, the number with less than five years' exposure who had done the same is unknown. An unknown number of men had, in addition, been moved to 'clean' departments within the viscose plant after periods of less than five years of work in polluted departments, health reasons being the most common cause. As a result of these uncontrollable factors it may be assumed that 'healthy' men could best stand the exposure and that such workers are over-represented in our material. This assumption, of course, presupposes that the neurological or psychic disturbances or both that usually have been the reason for the transfers are correlated with coronary heart disease, a question that cannot be answered at the moment.

The exclusion of patients receiving disability pensions for causes other than $\mathrm{CS}_{2}$ poisoning is most unfortunate, but was considered to be necessary because of the practical impossibility of forming an individually matched group from the paper mill when starting the retrospective selection from as early as 1942. A selection of controls on any other basis seemed to be haphazard. Reliable comparisons between mortality rates in the two factories were also impossible. The biases possibly introduced by various forms of selection and by the exclusion of workers receiving sickness insurance tend to dilute any effect exerted by $\mathrm{CS}_{2}$.

Against this background, the over-representation of coronary heart disease as the cause of death among the exposed workers seems to be an indication of a real effect. This finding is quite in conformity with the results of Tiller and his colleagues (1968). A more distinct difference between the groups with respect to 'coronary' ECG readings would have been a logical sequence. The tendency towards a higher frequency of post-exercise findings among the exposed subjects did not reach commonly accepted levels of statistical significance, but they still leave an impression of a higher morbidity. To what extent the diluting effects mentioned above have influenced the results is, of course, not possible to assess. Attention may also be paid to the high prevalence of 'coronary' ECGs (Table 9) among the controls. This is quite in accordance with earlier reported high prevalences in Finnish population studies (Karvonen, Blomqvist, Kallio, Orma, Punsar, Rautaharju, Takkunen, and Keys, 1966), and it makes the evaluation of a $\mathrm{CS}_{2}$ effect more difficult. 
One possible explanation for the small differences found in ECG variables is that $\mathrm{CS}_{2}$ makes the prognosis of coronary heart disease graver. This could result in a higher number of fatal attacks and would, therefore, not increase prevalence rates. Such a difference does exist between East and West Finland, the prognosis being graver in the East (Punsar, Karvonen, and Pyörälä, 1969).

The higher frequency of a history of angina found among the exposed subjects may indicate a real effect, but may also depend on a greater awareness of different sensations, provoked by the emotional stress of working in an environment where poisonings are known to happen. The higher blood pressure found in the exposed group is in accordance with earlier reports (Vigliani and Pernis, 1955; Gobbato et al.,1964; Goto and Hotta, 1967; Lilis et al., 1968; Navarro Martinez and Farina, 1969). Total serum cholesterol, triglycerides, free fatty acids, total lipids, plasma creatinine, and glucose tolerance were also measured in connection with this study; the results are reported and discussed in a separate article (Hernberg et al., 1970). In this context, it is relevant to mention that the mean plasma creatinine was higher in the exposed group $(\mathrm{t}=2.58, \mathrm{P}<0.01)$, that there was a slight tendency towards higher glucose values in the exposed group, and that no statistically or practically significant differences were found for any of the blood lipids. Since disturbances in the metabolism of some trace elements have been reported in experimental $\mathbf{C S}_{2}$ poisoning (Cohen, Scheel, Kopp, Stockell, Keenan, Mountain, and Paulus, 1959; Scheel, 1965), magnesium and zinc were measured from erythrocytes and plasma of some of the subjects. We found higher plasma magnesium but lower erythrocyte magnesium values among the exposed group (Hernberg, Mowé, Virkola, Partanen, and Nordman, 1969). The small differences found for the corresponding zinc values could have been due to chance. No rise in the excretion of zinc and magnesium could be shown at the time of transfer to exposure from 'clean' departments (Hernberg and Nordman, 1969). The significance of these findings for the pathogenesis of coronary heart disease, however, is unknown.

Even though the electrocardiographic differences indicating coronary heart disease were small and uncertain, the general impression is that $\mathbf{C S}_{\mathbf{2}}$ may have had some effect on the frequency of coronary heart disease, considering also the diluting effect of selection and the excess of coronary deaths in the mortality analysis. But even if so, our data are too vague to allow any conclusions to be drawn regarding whether or not the present TLV is safe with regard to coronary heart disease. One interesting result of this survey is the demonstration of the difficulties and fallacies that are inherent in any study dealing with coronary heart disease as a result of toxic exposure in any occupational population. We hope that a follow-up of both groups will provide us with more definite results.

We wish to thank Sven Punsar, M.D. for his invaluable help with the codification of the ECGs, Matti Viikeri, M.D. for reading the chest radiographs, and Professor Martti J. Karvonen, M.D., Ph.D., for his criticism of the manuscript. This study would have been impossible without the help of H. Th. Nyman, M.D., industrial physician of the viscose plant 'Säteri', and of Miss Liisa Innilä, Health Inspector of the 'Yhtyneet Paperitehtaat' paper mill. We are indebted to E. Sorsa, M.Sc., for providing us with the exposure data. Mrs. Pirjo Fahlström has performed the cumbersome statistical work, and Mrs. Tuulikki Poukka has given technical assistance with the preparation of the manuscript. Our thanks are due also to the managements and workers of both plants for their understanding attitude and their help with the practical arrangements. This work has been aided by grants from the Helena Lundqvist foundation.

\section{References}

American Conference of Governmental Industrial Hygienists (1968). Cincinnati.

Åstrand, P.-O., and Ryhming, I. (1954). A nomogram for calculation of aerobic capacity (physical fitness) from pulse rate during submaximal work. J. appl. Physiol., 7, 218-221.

Attinger, E. (1948). Chronische Schwefelkohlenstoffvergiftung unter dem "scheinbar ungewöhnlichem" Bilde einer schweren Gefässkrankheit. Schweiz. med. Wschr., 78, 667-669.

- (1954). Chronische Schwefelkohlenstoffvergiftung, ihre Pathogenese, ihre Frühdiagnose und ihre Verhütung. Schweiz. med. Wschr., 84, 912-913.

Blackburn, H., Keys, A., Simonson, E., Rautaharju, P., and Punsar, S. (1960). The electrocardiogram in population studies. A classification system. Circulation, 21, 1160-1175.

Brieger, H. (1961). Chronic carbon disulfide poisoning. J. occup. Med., 3, 302-308.

Cohen, A. E., Scheel, L. D., Kopp, J. F., Stockell, F. R., Keenan, R. G., Mountain, J. T., and Paulus, H. J. (1959). Biochemical mechanisms in chronic carbon disulfide poisoning. Amer. industr. Hyg. Ass. J., 20, 303-323.

Crepet, M., Gobbato, F., and Scansetti, G. (1956). Su alcuni aspetti clinici della vasculopatia da intossicazione cronica per solfuro di carbonio. Minerva med. (parte sci.), 47 (2) 379-387.

Epstein, F. H., Ostrander, L. D., Johnson, B. C., Payne, M. W., Hayner, N.S., Keller, J. B., and Francis, T. (1965). Epidemiological studies of cardiovascular disease in a total community-Tecumseh, Michigan. Ann intern. Med., 62, 1170-1187.

Gobbato, F., Sequi, G., and Turchetto, P. (1964). Rilievi clinicostatistici sulle alterazioni vascolari da solfocarbonismo cronico professionale. Minerva med. (parte sci.), 55, 4018-4021.

Goto, S., and Hotta, R. (1967). The medical and hygienic prevention of carbon disulphide poisoning in Japan. In Toxicology of Carbon Disulphide. Edited by Brieger, H., and Teisinger, J. Pp. 219-230. Excerpta Medica Foundation, Amsterdam.

Harashima, S., Toyama, T., and Sakurai, T. (1960). Serum cholesterol level of viscose rayon workers. Keio J. Med., 2, 81-90.

Hernbərg, S., Mowé, G., Virkola, P., Partanen, T., and Nordman, C-H. (1969). Magnesium and zinc values of erythrocytes and plasma for workers exposed to carbon disulphide. Wk-Environ.-Hlth, 6, No 2, 9-13.

- and Nordman, C-H. (1969). Failure to find increased excretion of zinc or magnesium in humans exposed to carbon disulphide. Med. d. Lavoro, 60, 163-168.

__ Partanen, T., Christiansen, V., and Virkola, P. (1970). Blood lipids, glucose tolerance, and plasma creatinine in workers exposed to carbon disulphide. Wk-Environ-Hlth, (In press).

Holmgren, A., and Strandell, T. (1961). On the use of chest-head leads for recording of electrocardiogram during exercise, Acta med. scand., 169, 57-62. 
Jacobs, M. B. (1949). The Analytical Chemistry of Industrial Poisons, Hazards, and Solvents, 2nd ed., p. 333. Interscience Publishers, New York and London.

Kannisto, V. (1947). The causes of death as demographic factors in Finland (Finnish).

Karvonen, M. J., Blomqvist, G., Kallio, V., Orma, E., Punsar, S., Rautaharju, P., Takkunen, J., and Keys, A. (1966). Men in rural East and West Finland. In: Ancel Keys et al. (ed). Epidemiological Studies Related to Coronary Heart Disease. Characteristics of Men Aged 40-59 in Seven Countries. (pp. 169-190). Tampere, Finland.

Lilis, R., Gavrilescu, N., Moscovici, B., Teculescu, D., Roventa, A., Nestorescu, B., Senchea, A., and Pilat, L. (1968). Effets cardiovasculaires de l'exposition prolongée au sulfure de carbone. Med. d. Lavoro, 59, 41-52.

Martino, P., Perrelli, G., and Coscia, G. C. (1964). Il quadro lipemico nel solfocarbonismo. Arch. Sci. med., 117, 124-130.

Metropolitan Life Insurance Company Statistical Bulietin, 40, 1959.

Minden, H. (1967). Literaturübersicht zur Pathogenese der chronischen Schwefelkohlenstoffvergiftung. Hygiene (Wien), 10, 722-728.

Navarro Martinez, N., and Farina, G. (1969). Contributo clinico statistico allo studio della vasculopatia solfocarbonica: analisi di 75 casi. Med. d. Lavoro, 60, 11-20.

Nordman, C-H., Partanen, T., and Hernberg, S. (1969). Coronary heart disease and risk factors among middle-aged men in relation to district of birth. Wk-Environ-Hlth, 6, No 2, 14-19.

Nunziante Cesàro, A. (1953). Il solfocarbonismo cronico quale encefalo-vasculopatia primitiva. Clin. med., 34, 731-743.

Oja, P., and Partanen, T. To be published.

Partanen, T. (1965). Statistics on cardiovascular diseases in Finland (Finnish). Finnish Heart Association, Helsinki (mimeo).

Přerovska, I., and Srbová, J. (1963). The serum biochemistry of subjects exposed to carbon disulfide, in correlation to arteriosclerosis. Pracov. Lék., 15, 25-30.

Punsar, S., Karvonen, M. J., and Pyöıälä, K. (1969). The difference between east and west Finland in the prognosis of coronary heart disease. Paper read at the III Medical Meeting, March 28-29, Helsinki.

von Rechenberg, H. K. (1957). Das vasculäre Spätsyndrom der chro- nischen Schwefelkohlenstoffvergiftung. Helv. med. Acta, 24, 510-513.

Ruikka, I. (1959). Postprandial serum turbidity in chronic carbon disulphide poisoning. A comparison of viscose rayon workers with healthy and atherosclerotic men. Ann. Med. intern. Fenn., 48, suppl. 31 .

Scheel, L. D. (1965). Biological changes involving metal ion shifts. Amer. industr. Hyg. Ass. J., 26, 585-592.

Taccola, A., and Majeron, M. (1964). L'ECG, nei soggetti esposti al rischio solfocarbonico. Folia med., 47, 225-237 (Napoli).

Tiller, J. R., Schilling, R. S. F., and Morris, J. N. (1968). Occupational toxic factor in mortality from coronary heart disease. Brit. med.J., 4, 407-411.

Toyama, T., and Sakurai, H. (1967). Ten-year changes in exposure level and toxicological manifestations in carbon disulphide workers. In Toxicology of Carbon Disulphide. Edited by Brieger, H., and Teisinger, J. Pp. 197-204. Excerpta Medica Foundation, Amsterdam.

Vigliani, E. C. (1954). Carbon disulphide poisoning in viscose rayon factories. Brit. J. industr. Med., 11, 235-244.

- (1961). Vergiftung mit Schwefelkohlenstoff. In Handbuch der gesamten Arbeitsmedizin, edited by E. W. Baader. Band II/1, pp. 313-325. Urban and Schwarzenberg, Berlin.

- and Pernis, B. (1955), Klinische und experimentelle Untersuchungen über die durch Schwetelkohlenstoff bedingte Atherosklerose. Ar h. Gewerbepath. Gewerbehyg., 14, 190-202.

Visconti, E. (1963). Rapporti tra alterazioni vascolari e modificazioni ematochimiche nel solfocarbonismo clinico. Folia med. (Napoli), 46, 1017-1037.

World Health Organization (1963). Réunion technique sur les enquêtes épidemiologiques concernant la fréquence des cardiopathies ischémiques. Bureau Régional de L'Europe, Copenhagen.

Wrońska-Nofer, T., and Nofer, J. (1967). Recherches expérimentales sur les troubles du métabolisme des lipides sous I'influence du sulfure de carbone. In Toxicology of Carbon disulphide. Edited by Brieger, H., and Teisinger, J. Pp. 161-164. Excerpta Medica Foundation, Amsterdam.

Received for publication February 6, 1970 